\title{
Islamic Ethics in Dialogue with Socrates, Jesus, and Confucius
}

\author{
M. Ashraf Adeel
}

\begin{abstract}
This paper argues that Islamic ethics is a retaliatory ethics only at the socio-political level. In personal morality, it resembles the ethics of Socrates and Jesus of not returning wrong for wrong. A comparison is also undertaken with Confucian ethics.
\end{abstract}

\section{Introduction}

The aim of this paper is to dispel the impression that Islamic ethics is just retaliatory or "an eye for an eye" ethics. While at the socio-political level Islam does consider the ethics of equivalent response to be justified, acceptable, and perhaps the only practicable ethics, at the level of personal morality or, what the Qur'an calls personal taqwa (piety), the preferred Qur'anic position is that of not returning wrong for wrong. In this regard, the Qur'an's position is similar to that of Socrates and Jesus' Sermon on the Mount. After an exposition of the basic tenets of Islamic ethics, a comparison is undertaken between it, Socrates' position in the early Platonic dialogues like the Apology and Crito, and the Sermon on the Mount. The goal is to substantiate the argument that Islamic personal ethics is similar, in fundamental respects, to Socratic and Christian personal ethics.

A comparison is also made between the Confucian emphasis on familial ties as foundational to Confucian ethics and Islamic ethics. Although there are competing interpretations of the significance of family relations for morality in Confucianism, one can discern a certain similarity between it on the one hand and Islam, Socrates and Jesus on the other as regards not returning wrong for wrong. ${ }^{1}$

The overall point of the paper is to emphasize the common grounds between Islamic and other ethical systems.

M. Ashraf Adeel is professor of philosophy at Kutztown University of Pennsylvania, Kutztown, PA. He earned his BA and MA at the University of Peshawar (Pakistan) and his PhD at the University of Hawai' $i$. His philosophical interests include the contemporary philosophy of language and science as well as modern Islamic thought. He teaches symbolic logic, introduction to critical thinking, introduction to logic, philosophy of language, philosophy of science, history of scientific ideas, American philosophy, interpretations of the Qur'an, and modern philosophy. 


\section{Islamic Ethics}

Seven things seem to be absolutely fundamental to Islamic ethics: freedom of choice, conscience (i.e., the ability to distinguish right from wrong), sound moral character as the only criterion of one's worth, total rejection of moral arrogance and self-righteousness, intention plus value/principle behind an action as the ultimate basis of its ethical worth, punishment equivalent to the crime in order to maintain social order, and a non-retaliatory or forgiving approach as the highest moral stance. This overall approach to ethics is then supplemented with higher values, which are all embodied in the names or attributes of God and toward which humanity needs to strive. Let us elaborate this picture a bit.

The idea of moral choice is fundamental to the attribution of moral responsibility in an ethical system. The Qur'an is replete with verses that hold all people responsible and accountable for their actions both in this world and in the hereafter. For example, "Then shall anyone who has done an atom's weight of good, see it. And anyone who has done an atom's weight of evil, shall see it (Q. 99:7-8).

In view of this comprehensive responsibility and accountability for one's actions, people must have the ability to choose their actions freely. In the Qur'anic worldview, the freedom to choose distinguishes humanity from the rest of God's creatures in nature: "We did indeed offer the Trust to the Heavens and the Earth and the Mountains; but they refused to undertake it, being afraid thereof: but man undertook it; - He was indeed unjust and foolish (Q. 33:72).

Commentators of the Qur'an generally agree that this "Trust" is that of free choice in doing what is obligatory, of being freely responsible before God for one's religious and moral duties. ${ }^{2}$ Nature lacks this ability, and humanity, which rose up to accept this grave and heavy Trust, exposes itself to the possibility of committing foolish and unjust acts. But, simultaneously, the immensity of this risk-taking elevates humanity above everything else in creation.

The question, then, is how does this free choice come into play in human nature? In other words, what are the psychological bases for such free choice in human nature? The Qur'an seems to root this choice in both the rational and affective aspects of human nature. The Qur'anic concept of a heart/mind $\left(a l-a f^{\prime} d a h\right)$ is critical here, for this is the seat of free choice. In other words, both our intelligence and our desires/emotions come into play when we exercise our choice to pick between things and actions. The Qur'an says: "It is $\mathrm{He}$ 
Who brought you forth from the wombs of your mothers when ye knew nothing; and He gave you hearing and sight and intelligence and affections: that ye may give thanks (to Allah)" (Q. 16:78). This concept is also reiterated in Q. 23:78, 46:26, and 67:23.

The term translated as "intelligence and affections," al-af"idah, literally means "hearts"; however, in the Arabic idiom it signifies heart/mind. This verse underscores that the senses, intelligence, and affections that are basic to human nature or one's personality are granted to the individual by the Creator. Thus it appears that the human will, which we exercise in all free choices, results from human affections as per the Qur'an: "Say, 'The Truth is from your Lord': Let him who will believe, and let him who will, reject (it)" (Q. 18:29).

The word translated as "who will" can also be translated as "who wants." The point is that human will is connected with human affections through a want or a desire. It is safe to conclude, therefore, that in the Qur'anic worldview the exercise of free choice or will is linked with affection. But, one must add here, the Qur'anic concept of heart/mind underscores that these affections and intelligence do not operate independently of each other, and hence intelligence is also involved in exercise of will or free choice.

Other verses point out that this heart/mind is the seat of free choice in matters of moral and religious duties, particularly those that speak of the human heart's "hardening" due to moral and spiritual violations (e.g., Q. 2:74, $5: 13,22: 53$, and 39:22). Such verses imply that making the right moral and spiritual choices "softens" the human heart and sensitizes it to the right kind of values in all realms.

The second basic idea of Islamic ethics is that of conscience, or the ability to distinguish right from wrong. The clearest statement that the individual's nafs, which is often translated as "soul" but which really covers both a person's physical and mental nature as a concept, has been given the ability to distinguish right from wrong is as follows: "By the Soul (nafs), and the proportion and order given to it, And its enlightenment as to what is wrong and what is right" (Q. 91:7-8).

So the human nafs or nature has the light to distinguish its right from wrong. This inherent ability of humanity constitutes the bedrock upon which the individual can raise the structure of a sound moral character, or what the Qur'an refers to as taqwā. This latter term is often translated as "fear of God"; however, according to Fazlur Rahman (1919-88), a great contemporary commentator of the Qur'an, it must be understood in the following way:

The term is usually translated by the words "fear of God" and "piety." ...The root of the term, wqy, really means "to guard or protect against 
something" and it has also been used in this literal sense in the Qur'an (e.g., 52:27; 40:9; 40:45; 76:11).

Hence Taqwa means to protect oneself against the harmful or evil consequences of one's conduct. If, then, by "fear of God" one means fear of the consequences of one's actions -whether in this world or the next (fear of the punishment of the Last Day) - one is absolutely right. ...

Considering all the verses in the Qur'an related to this concept, perhaps the best way to define Taqwa is to say that, whereas action belongs to man, real and effective judgment upon that action, as well as the standard whereby that action is to be judged, lie outside him. Similarly, in the case of the collective performance of a society, both the criterion of judgment upon it and the judgment itself transcend that society. When a man or society is fully conscious of this while conducting himself or itself, he or it has true Taqwa. This idea can be effectively conveyed by the term "conscience," if the object of conscience transcends it. This is why it is proper to say that "conscience" is truly as central to Islam as love is to Christianity when one speaks of the human response to the ultimate reality - which, therefore, is conceived in Islam as merciful justice rather than fatherhood.

Taqwa, then, in the context of our argument, means to be squarely anchored within the moral tensions, the "limits of God," and not to "transgress" or violate the balance of those tensions or limits. ${ }^{3}$

Rahman is using the term conscience in a very special sense here. It is not only the ability to distinguish right from wrong, but also acting upon what is right, and then realizing that the true criterion of the judgment of one's actions lies with God and not within oneself. This broader concept is of critical significance for Islamic ethics. However, the concept of conscience as an inherent ability of the human nafs to distinguish right from wrong is also clearly mentioned in Q. 91:7-8, quoted above.

The third element of Islamic ethics is that sound moral character is the only criterion for judging a person's worth. All other distinctions (e.g., race, color, language, and even religion) are relevant only insofar as they help strengthen one's pursuit of righteousness and do not conflict with this pursuit. In any other respect, they have no say in the matter of a person's moral worth in God's sight and cannot be used to discriminate among human beings by assigning them different moral stations. As the Qur'an proclaims:

O mankind! We created you from a single (pair) of a male and a female, and made you into nations and tribes, that ye may know each other (not that ye may despise (each other). Verily the most honored of you in the sight of Allah is (he who is) the most righteous of you. And Allah has full knowledge and is well acquainted (with all things). (Q. 49:13) 
The honored are those with God who are righteous. There is no other criterion. Nations and tribes are simply a way of recognizing each other. This is also true as regards humanity's various languages and colors, for "And among His Signs is the creation of the heavens and the earth, and the variations in your languages and your colors: verily in that are Signs for those who know" (Q. 30:22).

Thus these external factors have nothing to do with our moral worth. Rather, they are signs of God's creation and not of our supposed superiority or inferiority vis-à-vis each other. This is similar to the plurality of religions: "Those who believe (in the Qur'an), and those who follow the Jewish (scriptures), and the Christians and the Sabians - any who believe in Allah and the Last Day, and work righteousness, shall have their reward with their Lord; on them shall be no fear, nor shall they grieve" (Q. 2:62).

Again, righteousness is the criterion of reward before God. Belief in God that is, the embodiment of all positive values - and the Last Day (i.e., that one is going to be held accountable for one's actions in this life) ensure the right moral and spiritual attitude for working righteousness. In all matters, therefore, the ultimate and only criterion of honor and reward before God is righteousness. All other distinctions are either meant to accentuate our righteousness or to signify God's merciful signs through which we recognize each other.

Islamic ethics also rejects moral arrogance and self-righteousness. The earliest verses of the Qur'an's second chapter list the conditions for being able to receive moral and spiritual guidance from the Qur'an. The first condition is that of faith in the Unseen. This Unseen is obviously God, who transcends our comprehension, as do His names and attributes. As the French philosopher Emmanuel Levinas (1906-95) put it, we can never totally thematize or bring under our knowledge the Unseen that is God with all His attributes. ${ }^{4}$ Given this ever-transcendent character of God, the ultimate embodiment of all higher values, it seems that one can only do one's best to capture the spirit of a given higher value in one's actions, but can never be totally sure as to their real worth. Hence, one can never claim in arrogance that he/she is morally and spiritually better than others. Self-righteousness is completely ruled out by faith in the unseen perfect God. Rahman noticed this point, which is captured in the broader concept of conscience, in his analysis of the Qur'anic concept of taqwa. The judgment on our actions and the criterion of such judgment always lie outside us.

Next we turn to the criterion of the moral worth of an action in Islam: What factor(s) is/are ultimately both necessary and sufficient for the correctness of an action in a given situation? The Qur'an does value the consequences 
of an action, but its criterion for ethical correctness is not utilitarian. Actions are evaluated ultimately on the basis of the agent's intention and the value or principle for which they are performed. In this sense, Islamic ethics is primarily a virtue ethics that considers various virtues as values. It is the right intention and the right value or virtue, and not the consequences aimed at, that are both necessary and sufficient for making an action right, as the Qur'an proclaims: "Allah will not call you to account for thoughtlessness in your oaths, but for the intention in your hearts; and He is Oft-forgiving, Most Forbearing" (Q. 2:225) and

Call them by (the names of) their fathers: that is juster in the sight of Allah. But if ye know not their father's (names, call them) your Brothers in faith, or your maulas. But there is no blame on you if ye make a mistake therein: (what counts is) the intention of your hearts: and Allah is Oft-Returning, Most Merciful. (Q. 33:5)

Both of these verses point to right intention as being necessary for the rectitude of an action. Similarly, the Prophet famously stated: "Actions are only by intention." The idea is that an action's worth is determined by its underlying intention. Intentions, however, while necessary for determining the action's good or bad quality, are not sufficient for doing so. In addition to right intention, a person has to follow the right value or principle in doing that particular action, for only that can cause the action to be judged as morally correct. This seems to be the reason why the Qur'an elaborates on the concept of righteousness by pointing to examples of morally and spiritually righteous deeds.

It is not righteousness that ye turn your faces towards East or West; but it is righteousness - to believe in Allah and the Last Day, and the Angels, and the Book, and the Messengers; to spend of your substance, out of love for Him, for your kin, for orphans, for the needy, for the wayfarer, for those who ask, and for the ransom of slaves; to be steadfast in prayer, and practice regular charity; to fulfill the contracts which ye have made; and to be firm and patient, in pain (or suffering) and adversity, and throughout all periods of panic. Such are the people of truth, the Allah-fearing. (Q. 2:177)

Many other verses point to a host of deeds, principles, and values as righteous. It appears that they will have to be combined with the right intention in order to achieve moral and spiritual rectitude in one's actions. Simply having the right intention is not enough.

Once we have this criterion of righteous action, we can safely say that results, profits, and so on do not make an action moral, but that they are rather 
outcomes of the action's morality. One should do what is right without looking at the outcome, although the outcome would be always better than immoral choices.

The sixth important idea in Islamic ethics is that qișās (the law of equality) is essential for maintaining a just social order:

O ye who believe! The law of equality is prescribed to you in cases of murder: the free for the free, the slave for the slave, the woman for the woman. But if any remission is made by the brother of the slain, then grant any reasonable demand, and compensate him with handsome gratitude, this is a concession and a Mercy from your Lord. After this whoever exceeds the limits shall be in grave penalty. In the Law of Equality there is (saving of) Life to you, O ye men of understanding; that ye may restrain yourselves. (Q. 2:178-79)

The prohibited month for the prohibited month, - and so for all things prohibited, - there is the law of equality. If then any one transgresses the prohibition against you, Transgress ye likewise against him. But fear Allah, and know that Allah is with those who restrain themselves. (Q. 2:194)

Nor take life - which Allah has made sacred - except for just cause. And if anyone is slain wrongfully, we have given his heir authority (to demand qisas or to forgive): but let him nor exceed bounds in the matter of taking life; for he is helped (by the Law). (Q. 17:33)

The recompense for an injury is an injury equal thereto (in degree): but if a person forgives and makes reconciliation, his reward is due from Allah. For (Allah) loveth not those who do wrong. (Q. 42:40)

In all of these verses, the Qur'an is focused on the law of equality or equal retaliation. Verses 2:178-79 also provide us with the justification of such a law, and verses 2:194 and 17:33 set clear limits by recommending restraint and not exceeding the bounds.

It is stated that in this law there is life to humans. The best interpretation of this idea appears to be that just recompense can keep a social order alive, for without it there would be only chaos and anarchy. If people are not punished for their evil deeds, then the society can slowly collapse. If they are punished too harshly or too mildly in comparison to their crime, then again chaos will appear sooner or later. Thus a society's continued existence depends upon the law of equal punishment or retaliation.

Of course the authority to forgive lies with the deceased's heir or the injured party. The Qur'an leaves room for such a course of action. It must be noted, however, that this authority is granted only to the two above-mentioned 
individuals. Neither the state nor the society can exercise such authority on either individual's behalf, for at the public level the law of equality must be maintained in order to keep the social order alive. Hence, it appears that the Qur'an upholds the law of equality or equal retaliation on the public or societal level.

However, turning now to our seventh point, the Qur'an's preferred route at the level of personal ethics seems to be that of forgiveness and non-retaliation. In continuation of Q. 42:40 quoted above, the Qur'an declares:

But indeed if any do help and defend themselves after a wrong (done) to them, against such there is no cause of blame. The blame is only against those who oppress men and wrong-doing and insolently transgress beyond bounds through the land, defying right and justice: for such there will be a penalty grievous. But indeed if any show patience and forgive, that would truly be an exercise of courageous will and resolution in the conduct of affairs. (Q. 42:41-43)

These verses are not addressed to the state or social institutions; rather, they are addressed primarily to individuals. The basic idea here is that there is no blame in seeking just recompense if one has been wronged. But if one decides to forgive and not return wrong for wrong, then one attains a higher level of personal morality, a morality of "courageous will and resolution" in the conduct of affairs. It is clear from the language (even in translation) that this morality of "courageous will and resolution" is the preferred morality of the Qur'an. The Qur'an uses the same terminology elsewhere, as in:

Ye shall certainly be tried and tested in your possessions and in your personal selves; and ye shall certainly Hear much that will grieve you, from those who received the Book before you and from those who worship many gods. But if ye persevere patiently, and guard against evil, - then that will be a determining factor in all affairs. (Q. 3:186)

If we look at the Arabic text, the last words of this verse are the same as in Q. 42:43, quoted above, and can be translated as "so that will be [the] exercise of [one's] courageous will and resolution." In this verse as well, therefore, the Prophet and Muslims are asked to be patient and guard against the temptation of returning evil for evil. Again this is done in a language that really underscores the preferred and praiseworthy nature of such a recourse. Hence, the common impression that the Qur'an prefers the morality of equal retaliation at the personal level as well is simply a mistake. Qur'anic ethics prefers that at this level wrong not be returned for wrong, for the law of mercy is pre- 
ferred. But at the societal level, the law of justice is considered essential for keeping the social order alive.

Islamic ethics is built around these seven basic concepts, upon which the system of virtues, values, and duties recommended by the Qur'an is ultimately based. One cannot discuss all such religious, social, or moral duties, values, and virtues in order to understand how they relate to the seven concepts outlined here; however, moral choice, conscience, and the avoidance of moral arrogance would clearly apply in all matters. The same goes for the idea of intention plus value (or principle) as a basis for judging the rectitude of human actions. Similarly, a sound moral character as the only basis of award and honor in moral matters (i.e., a non-discriminatory attitude) and the law of equality at the level of social order are essential for creating the foundations of a social environment in which virtue can prevail and flourish. Lastly, the principle of not returning wrong for wrong (i.e., forgiveness) at the personal level is meant to encourage the law of mutual mercy in society and also ultimately helps to deepen our personal piety $(\operatorname{taq} w \bar{a})$.

Virtues and values like faith, prayer, charity, moderation, the sanctity of life, freedom of religion, and the dignity of humanity all relate to these seven basic concepts in their own ways. In particular they provide, in combination with the agent's necessary right intention, the sufficient basis for giving different actions their moral rectitude and excellence. Therefore, they are central to the Qur'anic ethical universe.

\section{Comparison}

One of the key ideas in ethics is that of never returning wrong for wrong. One finds it in Socratic as well as in Christian ethics, and also tangentially present in Confucian ethics. However, neither Socrates nor Jesus and Confucius seem to ignore the requirements of justice at the level of public order. The following brief analyses of the positions taken by these figures are meant to underscore this point.

\section{Socratic Ethics}

In the early Platonic dialogues, which are generally considered representations of the historical Socrates, Socrates takes the position that we should never return evil for evil. He upholds the same principle in Crito, for example, in which he and his longtime friend Crito debate whether or not he should escape from prison in order to save himself from the unjust punishment of death pronounced upon him by the Athenian jury. Even though his life is at stake, Socrates stead- 
fastly refuses to return evil for evil and inflict injury upon the Athenian laws that, he contends, have produced, nourished, and educated him. At one point in their conversation, he makes the following remark:

Then we ought not to retaliate or render evil for evil to anyone, whatever evil we may have suffered from him. But I would have you consider, Crito, whether you really mean what you are saying. For this opinion has never been held, and never will be held, by any considerable number of persons; and those who are agreed and those who are not agreed upon this point have no common ground, and can only despise one another, when they see how widely they differ. Tell me, then, whether you agree with and assent to my first principle, that neither injury nor retaliation nor warding off evil by evil is ever right. And shall that be the premise of our agreement? Or do you decline and dissent from this? For this has been of old and is still my opinion; but, if you are of another opinion, let me hear what you have to say. If, however, you remain of the same mind as formerly, I will proceed to the next step. (Crito, 49c-e)

Here the situation is different than in Analects 13:18. Socrates is not asking us to cover up our relatives' crimes, but seems to be saying that, relative or not, we should never retaliate with an act in kind against anyone who commits an evil act against us at the personal level. I say "at the personal level" because there is ample evidence in Socrates' life that he would not tolerate the disruption of public order and justice by anyone. He does, for example, say the following in the Apology, his defense in the Athenian court:

... wherever a man's place is, whether the place which he has chosen or that in which he has been placed by a commander, there he ought to remain in the hour of danger; he should not think of death or of anything, but of disgrace. And this, O men of Athens, is a true saying. (Apology, 28d)

Socrates' point here seems to be that anyone who violates an order that has been given in the best interest of the public good will be disgraced and can be punished for committing such a crime. He himself could have been justly punished, he says, if he had violated the orders given to him in the battles that he had fought for his city or orders given to him by the gods for leading the life of a philosopher. This much Socrates clearly says in the Apology 29a. Therefore, his claim that we should never return evil for evil must be viewed as applicable only at the personal level. We should not return evil for evil if such a non-retaliatory attitude does no damage to the public good. If such a view of Socrates' position is correct, then his position is also similar to the one elaborated above in relation to Islamic ethics. 


\section{The Ethics of Jesus}

The Sermon on the Mount is considered to be one of the central texts of Jesus' ethical teachings. ${ }^{5}$ From the point of view of our discussion here, the following verses are the most important:

You have heard that it was said, "An eye for an eye and a tooth for a tooth." But I tell you not to resist an evil person. But whoever slaps you on your right cheek, turn the other to him also. If anyone wants to sue you and take away your tunic, let him have your cloak also. And whoever compels you to go one mile, go with him two. Give to him who asks you, and from him who wants to borrow from you do not turn away. (Mathew 5:38-42)

These verses enunciate the Christian principles of non-resistance of evil and turning the other cheek. These verses have elicited various responses throughout history. Friedrich Nietzsche (1844-1900) famously called this teaching the "morality of slaves." But figures like St. Augustine of Hippo (354-430) and St. Thomas Aquinas (1225-74) defended these principles while simultaneously reconciling them with the idea of public good and justice. As Howard Clarke puts it:

Augustine, living in a Christian empire threatened by heretics from within and invaders from without, qualified the Sermon's pacifism with his "just war" theory, arguing that in this imperfect world a legitimately constituted government has the right to use armed force in maintaining peace, order, and justice. Aquinas was in agreement, and with an eye to the Israelites' OT battles, he also allowed for the violent repression of disruptive heresies, but only "to prevent them from hindering the faith of Christ."

Similarly, Clarke notes that Martin Luther (1483-1546) acknowledged that the above-quoted verses are at odds with other verses, where it is ordained that crime deserves punishment. For example: "They that take the sword shall perish with the sword" (Mathew 26:52). According to Clarke, Luther resolves this conflict by rejecting the traditional interpretation:

$\mathrm{He}$ [Luther] dismissed one traditional explanation, that this was another of the "counsels of perfection" applicable to the spiritually enlightened, preferring instead to distinguish between "two kingdoms": the spiritual kingdom of God, present in the private lives of true Christians; and the secular - and overwhelmingly evil - kingdom of the world, where secular authorities have the responsibility to use coercion for the wellbeing of their citizens (which unfortunately leaves unresolved the problem of border conflicts between the two kingdoms). He also allowed for defensive wars and wars between equals, distinguishing between self-defense and defense of others. "Christians may seek retribution, justice, protection and help for others." 
Thus evil may be resisted in the service of those who are unable to do so, such as parents' obligation to protect their children or the state's obligation to defend its citizens. ${ }^{7}$

It is, however, possible to reconcile these two sets of verses by sticking to the traditional explanation, namely, that at the personal and private level one can adopt a spiritually more challenging and courageous course and turn the other cheek and refrain from resisting evil. However, at the level of the public good or of maintaining a just public order, one will have to adopt the law of equality that seems also to be embodied in "They that take the sword shall perish with the sword."

\section{Confucian Ethics}

In Confucianism, the virtue of not returning wrong for wrong should apparently flow from the central virtue of ren (i.e., humaneness, humanity, or benevolence). Recent literature provides two schools of thought in this regard. One school, led by Liu Qingping, argues that Confucianism is basically consanguinism (i.e., the root of morality is family love), while the other school, led by Guo Qiyong considers this root to be the individual's moral heart/mind, which is endowed with universal human love by Heaven. ${ }^{8}$ According to the first school, we learn to develop universal human love through filial piety and brotherly respect. This love for the family is a kind of a training ground for us, for through it we slowly attain the power to love other human beings as well.

On the other hand, Guo and his followers believe that all human beings are given a moral heart/mind by Heaven, much as the moral heart/mind spoken of in the Qur'an. This moral heart/mind is first trained in the family through filial piety and respect for your brother or other relatives. It slowly develops into respect for the ruler as well. Thus through $l i$ (i.e., the virtue of acting with propriety in family relations), one learns to act righteously in relation to all humanity. Through the appropriate love and respect of one's family, one learns to develop a universal love of all of humanity, which is what the virtue of ren or humanity really is. I have tried to adjudicate between these two schools of thought elsewhere. ${ }^{9}$ It is enough to note here that Confucianism seeks to achieve the universal love of humanity or the virtue of ren in human beings.

Once this virtue has been achieved through $l i$ in rites in relation to parents, relatives, and the ruler, one then has the capacity to act with yi (righteousness). According to scholars, $y i$ has the components of zhong (doing one's best) and $s h u$ (reciprocity, altruism, and consideration for others). Shu seems to be an equivalent of the concept of forgiveness, for it is the Confucian version of the 
Golden Rule. Analects 15:23 states: "Zigong asked, saying, 'Is there one word which may serve as a rule of practice for all one's life?' The Master said, 'Is not RECIPROCITY such a word? What you do not want done to yourself, do not do to others."

Other passages in the Analects, like 12:2 and 6:28, seem to have a similar import. Apparently, one cannot be truly and deeply righteous without treating others in line with the analogy of one's own self. Here, Confucianism seems to rule out retaliatory ethics at the personal or private level. This can happen at two levels. First, when dealing with one's parents and relatives, one has to act not with righteousness always but with grace, as Guo contends in interpreting some particularly difficult passages in the Analects and Mencius. In Analects 13:18, Confucius talks about fathers and sons covering up for each other, and in Mencius 7A35 and 5A3, Mencius talks about King Shun leaving his empire to help his father escape the punishment for murder (7A35) and bestowing a princely status upon his murderous brother (5A3). Guo contends that these passages point not to blood relations being superior to morality based on humanity, but only to the idea that blood relatives need to be treated with grace as far as possible. ${ }^{10}$ Perhaps righteousness cannot be violated in such cases as well, but grace and a forgiving attitude can be adopted if one can do so without violence to the universal love of humanity or the public good.

Second, once we train ourselves in this attitude of grace and forgiveness in the context of family relations, we can extend the same attitude or principle to humanity in general at the private and personal level, as long as we do not violate the principles of the universal love of humanity or righteousness in relation to humanity at the public level. This understanding of Confucianism, I believe, makes it similar to Islamic ethics in this matter. As noted above, Islamic ethics insists upon the law of equality to protect justice at the level of public order, but simultaneously prefers forgiveness at the personal level.

\section{Conclusion}

The foregoing elaboration of Islamic ethics and its comparison with Socrates, Jesus, and Confucius show a common thread running through these systems of morality. In order to maintain the public order and its justice, these systems recommend the law of punishment equivalent to the crime for all. Islamic ethics takes this law to be a source of life for society. Similarly Socrates, Christian authorities, and Confucian scholars recognize the necessity of such a law of justice for maintaining the social order. However, at the level of personal morality, all these ethical systems seem to prefer a morality of forgiveness and not 
returning evil for evil. This is well-known in the cases of Socrates and Jesus. We have seen that Islamic ethics is no different in this regard and recommends a similar attitude as the highest moral stance at the personal level. The idea that Islamic ethics is only a retaliatory ethics at all levels is, therefore, simply mistaken. It is also important that Confucian scholars allow room for grace and forgiveness at the personal level, particularly in the treatment of relatives. Such grace could be extended to other humans at the personal level as long as it does not violate the requirements of public virtue.

In a nutshell, therefore, the general spirit of Islamic ethics is similar to the ethics of Socrates, Jesus, and Confucius.

\section{Endnotes}

1. All translations of the Qur'an are from Abdullah Yousaf Ali, The Meaning of the Qur'an (Beltsville, MD: amana publications, 1999). All translations of Plato's Apology and Crito are from G. M. A. Grube, The Trial and Death of Socrates, $3 \mathrm{~d}$ ed., rev. John M. Cooper (Indianapolis and Cambridge: Hackett Publishers, 2000).

2. For example, see the discussions in Tafsìr Ibn Kathīr at www.tafsir.com/default. asp?sid $=33 \&$ tid $=42279$ and Tafsir $r$ al-Jalalayn at www.altafsir.com/Tafasir.asp? $\mathrm{tMadhNo}=1 \& \mathrm{tTafsirNo}=74 \& \mathrm{tSoraNo}=33 \& \mathrm{tAyahNo}=72 \& \mathrm{tDisplay}=\mathrm{yes} \&$ UserProfile $=0$ \&LanguageId=2. Also see Ali, Holy Qur'an, footnotes 3777-79.

3. Fazlur Rahman, Major Themes of the Qur'an (Minneapolis: Bibliotheca Islamica, 1999), 28-29.

4. E. Levinas, Totality and Infinity: An Essay on Exteriority, tr. Alphonso Lingis (Pittsburgh: Duquesne University Press, 1969).

5. See Jeffrey S. Siker, Scripture and Ethics: Twentieth-Century Portraits (Cary, NC: Oxford University Press, 1996), 51.

6. See Howard Clarke, Gospel of Matthew and Its Readers: A Historical Introduction to the First Gospel (Bloomington, IN: Indiana University Press, 2003), 101.

7. Ibid., 102.

8. For an understanding of these two schools see Guo Qiyong, "Is Confucian Ethics a 'Consanguinism'?" Dao: A Journal of Comparative Philosophy 6, no. 1 (March 2007): 21-37 and Liu Qingping, "Confucianism and Corruption: An Analysis of Shun's Two Actions Described by Mencius," Dao: A Journal of Comparative Philosophy 6, no. 1 (March 2007): 1-19.

9. See my "Islamic Ethics and the Controversy about the Moral Heart of Confucianism," Dao: A Journal of Comparative Philosophy 7, no. 2 (2008): 151-56.

10. Guo, "Confucian Ethics," 26. 